\author{
Oksana DESYATNYUK, \\ Taras MARSHALOK
}

\title{
ANTI-CYCLICAL FISCAL REGULATION OF THE WORLDWIDE COUNTRIES' ECONOMIES - OPPORTUNITIES FOR UKRAINE
}

\begin{abstract}
The state fiscal policy and its instruments are the main means of economic fluctuations management and they occupy a leading place in the system of the state anti-cyclical regulation of the economy. Special theoretical and methodological aspects of the fiscal policy and analysis of its influence on the course of the economic cycle were well-reasoned on the ground of a large number of scientific publications. However, it is relevant to research into this problem using the pragmatic approach, which will allow to obtain qualitative scientific results and make the necessary conclusions. In particular, the analysis of fiscal processes in the countries with different economic development and social standards will allow to distinguish the strengths and weaknesses of the opposing patterns of fiscal policy models and types and will determine the impact of such policies on economic growth and overcoming the economic crises in these countries.
\end{abstract}

(C) Oksana Desyatnyuk, Taras Marshalok, 2019.

Desyatnyuk Oksana, Department of taxes and fiscal policy, Ternopil National Economic University, Ternopil, Ukraine. okster2014@gmail.com.

Marshalok Taras, Department of taxes and fiscal policy, Ternopil National Economic University, Ternopil, Ukraine. marshaloktm@gmail.com. 


\section{Key words:}

Anti-cyclical economic regulation, fiscal policy, socially-oriented fiscal policy, liberal fiscal policy, discretionary and non-discriminatory fiscal instrument, GDP, government deft, Government revenues, government expenditures.

JEL: E62.

\section{Analysis of recent researches and publications}

The problem of economic cycles is researched by many leading scientists, for example, M. Tugan-Baranovsky, M. Kondratiev, K. Zhjuljar, Joseph Kitchen, J. Schumpeter. Modern foreign scientists who research into anti-cyclical regulation problems are : P. Douglas, C. Plosier, E. Prescott, P. Samuelson, R. Solow, W. Sven, F. Kiddland, H. Minski, among the domestic scientists it is important to highlight T Bogdan, D. Lukyanenko, A. Poruchnik, Y. Stolyarchuk, V. Satsyk, O. Laktionova. publications. However, there is still an unsolved dilemma: which one of the fiscal policy models is more effective in overcoming economic imbalances and achieving economic equilibrium than others.

\section{Main purpose of the article}

In the research, our aim is to observe the fiscal policy models in the worldwide countries, to determine their effectiveness in preventing economic imbalances and achieving economic equilibrium. To propose an effective model of fiscal policy that would facilitate rapid economic development in Ukraine. 


\section{Methodology of the research}

In the course of the research, general scientific and empirical methods of economic science, based on a systematic approach, are used; in particular: dialectical and logical methods of scientific knowledge, analysis and synthesis, generalization, graphical and scientific abstraction - in the study of the fiscal policy influence on economic development in countries of the world and in Ukraine.

\section{Results and disscussions}

In order to reveal the economy problems, to understand the causes of negative trends in the socio-economic sphere of the worldwide countries and to develop effective ways to overcome economic imbalances in Ukraine, it is important to analyze the macroeconomic and fiscal conditions of the developed countries : the USA, Germany and Sweden; of the fast-developing countries like Poland and Slovakia; of the countries that according to the international organizations suffered the greatest economic losses after the crisis of 2008-2009 (Greece and Iceland) and of Ukraine, using these aspects: budget revenue and spendings dynamics, budget deficit, level and changes in government debt.

In order to reveal trends in these countries, we need to compare the dynamics of GDP and the changes of its indicator from 1991-2017 to the base year of 1991 (see figure 1).

It is important to research the dynamics of GDP in these countries by choosing the base year of 1991. Due to the fact that in 1990 the world's largest state (the USSR) ceased to exist, these historic events undeniably had a great impact on all countries of the world and as a consequence, on the economic situation in the global dimension. It was in 1991 when the former Soviet republics gained their independence and began the path of their establishment .

Analyzing the selected array of statistical data, we can draw the following conclusions. 
Figure 1

The dynamics of GDP from 1991-2017 to the base year of 1991 in the USA, Europe and Ukraine*

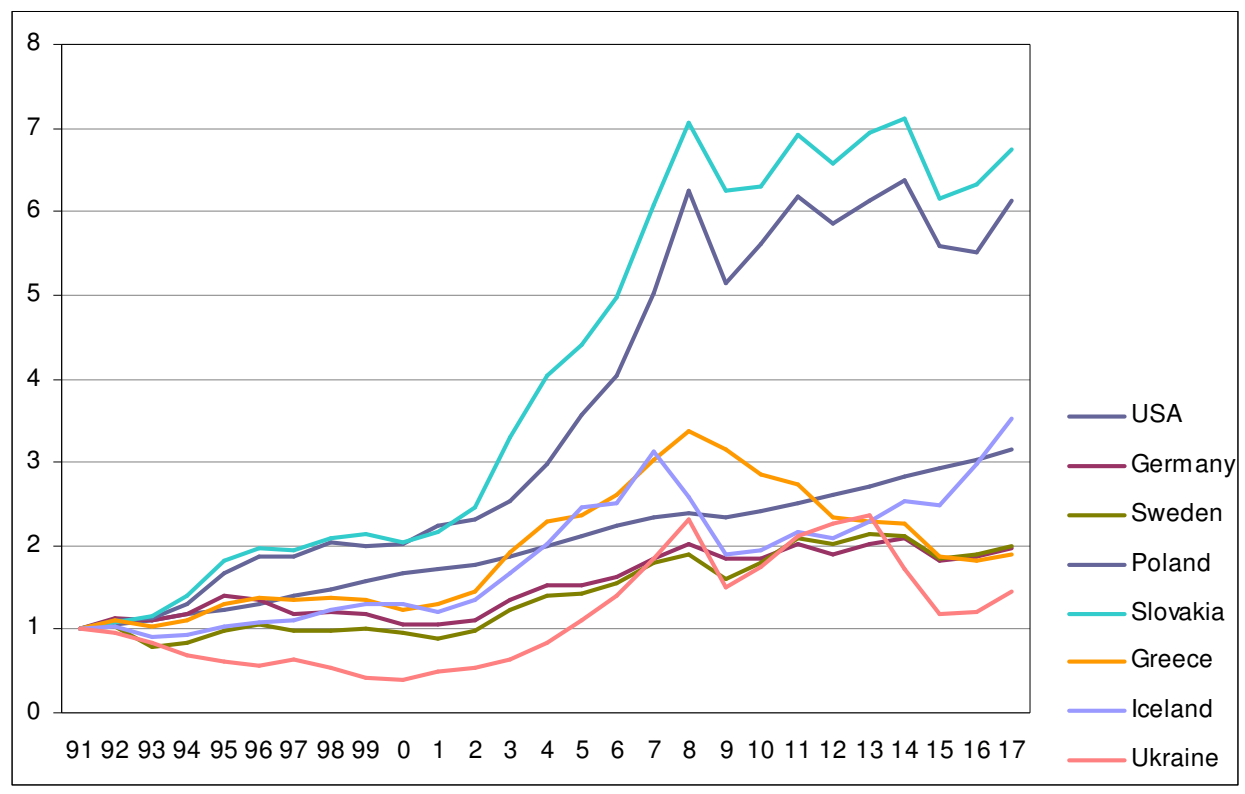

${ }^{*}$ Created by author, based on $[1 ; 2 ; 3 ; 4 ; 5 ; 6]$

The GDP dynamics is characterized by ascending dynamics from 1991 to 2008 inclusively. The GDP of the world leaders (the USA and Germany) has grown in relation to the base indicator. From 1991 to 2008, the GDP of the USA has grown 2.4 times compared to the base year of 1991 (which is 240\%). Such an increase was marked by a stable annual growth of $0.01 \%$, (which is $10 \%$ annually), while in 2009, US GDP growth paused and even slightly decreased for the first time in 16 years. The reason for this recession was the financial and economic crisis, which began in 2008 due to economic imbalances in the United States of America. Therefore, we can state that the USA is the country where the global financial and economic crisis of 2008-2009 began to emerge, and later spread around the world.

If we talk about the economic advancement of the most developed country in Europe - Germany, it is important to point out that in this country the changes in gross domestic product were less dynamic. The largest increase of GDP was 
ISSN 2519-4070

in 1992 - 1995. During this exploratory period, Germany's GDP growth reached a mark of «1.4» in the base year of 1991 (an increase of $40 \%$ over four years). But from 1996 to 2002 there was a reduction in GDP growth, which dropped to a mark of «1,1», comparing to 1991. However, there was a rapid increase in GDP growth in Germany from 2002. GDP was doubled by 2008 in comparison with 1991, which can be the evidence of the government effective steps towards economic development. However, the crisis of 2008-2009 influenced the economic situation in Germany, GDP in 2009 and 2010 reduced to 2007 figures - from mark «2» to " 1.8 ", while in 2011 the recovery of the economic upward conjuncture began and the GDP index grew to the level of 2008. The year of 2015, when the GDP index reduced slightly, was unusual for Germany.

The heterogeneous GDP growth dynamics in Germany can be explained by the short economic cycles which began to appear in Europe and had the greatest impact on the economies of powerful European countries. Specific reasons of a significant reduction in gross domestic product can be explained with the Asian crisis of 1996. According to analysts, this crisis led to a drop in world GDP by 2 trillion dollars and to the crisis of 1998 in the Russian Federation, which resulted in a default. Due to the interdependence between the European and Russian markets, Europe's countries were strongly affected by the crisis in Russia, which led to a reduction in german GDP.

In accordance with the trends, Sweden is the most stable country and has been the least exposed to economic crises. The particularity of this country is a clearly expressed socially-oriented model of public administration, with a high level of state redistribution of GDP. This is what influenced the dynamics of gross domestic product in this country. Particularly, macroeconomic dynamics is stable during all of the period. In the years of world economic shocks, Sweden did not succumb to economic turbulence, with the exception of only 2009, when the country's economy «lost weight» in comparison with 2008 ( the GDP in 2009 was «1.6», while in $2008-$ - 1.9» to the base year of 1991). However, Sweden managed to quickly recover from the effects of the economic crisis. In 2010, the country's economy has already grown to an index of «1.8». That means the effectiveness of the chosen economic doctrine of a socially oriented type. It is very important to emphasize on the fact that it is not right to compare the recovery rates of Sweden and the United States, because they are completely different in terms of economic world potential of the state. In particular, Sweden does not have such a powerful industrial sector of the economy as the USA does.

As an useful example for Ukraine, we can analyze economies of Poland and Slovakia, which are the countries of the former Socialist camp. Over the analyzed period, the GDP of these countries increased more than 6 times ( in Poland in 2017 the figure was «6.1» to the base year 1991, in Slovakia - «6.7»). 

countries' economies - opportunities for Tkraine

The result of such economic changes are the reforms in all sectors of these countries economy. Starting from the principles of state administration, keeping to the rule of law, the economy reformation to the market type, the reform of social protection, compliance with the European Union standards in the field of fiscal policy. And a determinative factor of rapid economic upswing is the qualitative establishment of reforms with the financial support of the European Union, compliance with the basic fiscal rules.

However, despite the rapid pace of economic and social development of Poland and Slovakia, the crisis of 2008-2009 had a powerful negative impact on the economies of these Eastern European countries. In 2009 Poland's GDP fell to the «5.1» compared to the base year, while in 2008 this figure was «6.2», while in 2010 the value of the indicator was already «5.6», and in 2011, the country managed to reconstruct the crisis value of GDP with the indicator of «6.2».

The similar situation is with Slovakia, where GDP reduction in 2009 reached the value of «6.3» in comparison with «7.1» in 2008. However, in 2011 there was a rapid increase in the macroeconomic index to the level of «6.9» compared to 1991.

Slovakia and Poland are unique economy examples for other countries. Only for 26 years they managed to increase their gross domestic product to the highest point among all of the countries of the European Union and among all of the countries of the former socialist camp. These states chose the right economic models of development and became leaders in economic development in the world.

Iceland and Greece have diametrically opposite experience, these countries suffered the most significant negative economic consequences from the financial and economic crisis. Only the effective actions of the world financial community aimed at rescuing the economies of these countries and financial assistance from world creditors did not allow these countries' economies to plunge into prolonged depression. Iceland's gross domestic product in 2009 dropped significantly compared to 2008 . If the value of the indicator was «2.6» in 2008 , then in 2009 it was «1.9» compared to the base year of 1991. At that time, in 2007 , the value of this indicator was «3.1». That means a significant reduction of Iceland's GDP during 2007-2009. Such negative consequences happened due to the effect of the financial and economic crisis in the world and to the disappointing state economic conjuncture.

Analyzing the trends of economic development in Greece, we can state the following dynamics: The country was able to increase its GDP more than three times during 17 years from 1991, the index in 2008 was - «3.4» compared to the base year of 1991. Such growth was caused by a significant financial 
ISSN 2519-4070

assistance from the European Union. Since 2009, the Greek economy has been gradually decreasing, which is clearly reflected in the dynamics of GDP. If the value of GDP in 2009 was «3.1» compared to the base year of 1991, then in 2017, this figure dropped to «1.9». We can observe that GDP of Greece decreased almost twice for the past 9 years. This tendency testifies to the economically ineffective steps of the Greek government in overcoming the effects of the economic crisis. That also means that the crisis in Greece continues by this day.

Among all the analyzed countries, the greatest interest is Ukraine, where during the entire period of independence we can observe a clearly expressed economic instability. The state that gained independence in 1991, is still at a «low start» of economic transformations. Economic processes in the country are proposed to be divided into three periods.

- 1st period - «Period of lost opportunities, economic depression», duration from 1991 to 2004.

- 2nd period - «The period of» revolutions «and» political upheavals» the duration from 2005 to 2013.

- 3rd period - «Period of military aggression, gradual economic growth» - the duration from 2014 by this day.

Each of the periods has its own peculiarities, in the first period, the economy of Ukraine was in a difficult position. Unstable political, groundless government steps in the economy, failed privatization. Irresponsible and chaotic steps by the government in the fiscal sector did not provide the necessary process in establishing clear trends of economic development. GDP of Ukraine from 1991 to 2004 fluctuated within the «0.8» index compared to the base year of 1991. The worst figures were recorded in 1999 and 2000, when the gross domestic product was less than $50 \%$ of GDP in 1991. There was the greatest economic depression in the history of independent Ukraine in those years. The reason for the deep economic crisis of the state can be explained by the economic crisis that rocked the Russian Federation, which was the largest economic partner of Ukraine. These conditions showed the huge dependence of the Ukrainian economy on the economic conjuncture of the Russian Federation. In post-crisis years, however, despite some economic progress, Ukraine still failed to achieve the desired result. The second period, stage between the two revolutions, was slightly better. The arrival of new political elites as a result of the "Orange Revolution» provided some economic recovery, which led to an increase in GDP of Ukraine to the indicator of «2.3» in 2008, which is considered to be the best indicator and the best period of economic growth of Ukraine's economy. However, the economic crisis of 2008-2009, once again slowed the economic growth down, GDP in 2009 was «1.5» compared to the base year of 

countries' economies - opportunities for Tkraine

1991. But in 2010, the economic growth was successfully restored, which lasted until 2013 inclusively. The level of gross domestic product in 2013 was «2.4» compared to the base year of 1991.

Unfortunately, the political issues, a radical change in the political vectors of the the government, which were opposite to the determined social values, led to significant transformational changes. The «Revolution of Dignity» led to a change of political elites and to Russian Federation's military aggression. The third period began in 2014, as a result of the occupation of the territory part where the largest number of industrial enterprises was concentrated (metallurgy, coal industry). In 2014, , the loss of the part of Ukrainian economic potential due to occupation made the gross domestic product fall to 1.7. The economic downturn lasted for the next two years - in 2015 and 2016, the country's GDP was only $1.2 \mathrm{bp}$ (base points) of GDP in 1991. However, already in 2017, the macroeconomic indicator grew to a value of «1,4».

So, after analyzing the economic dynamics during 1991-2017, we can draw the following conclusions.

Post-Soviet Ukraine is the state that had the longest period of overcoming the economic downfall, the phase of economic depression lasted for 13 years from 1991 to 2004, after what an economic development began in the country. Ukraine failed to take advantage of the chance for rapid economic growth, which happened in Poland and Slovakia - countries of the former socialist camp. These states managed to increase GDP by more than 6 times in 26 years. Such an increase means the effective steps taken by the governments of these countries, effective reforms, and the elimination of corruption, which did not happen to Ukraine in 26 years. The GDP dynamics in Poland and Slovakia shows an absence of deep economic crisis (for 26 years). Economic dynamics were only upward without deep shock periods, even in the context of regional crises (default in Russia in 1998) and the global financial and economic crisis in 2008-2009.

However, economic dynamics, growth or reduction of GDP show the existence of processes that happen under the influence of certain economic indicators, the governmental usage of certain financial and fiscal instruments.

Along with the analysis of the gross domestic product, it is important to research the indicators of state debt, incomes and expenditures of the budget in terms of years. This can help us to draw conclusions about the measures taken to prevent economic crises and the instruments that governments of these countries use under the condition of economic equilibrium. 
Figure 2

Government debt dynamics, government revenues and expenditures in the USA, Germany and Sweden in 1995-2017 (\% of GDP)*

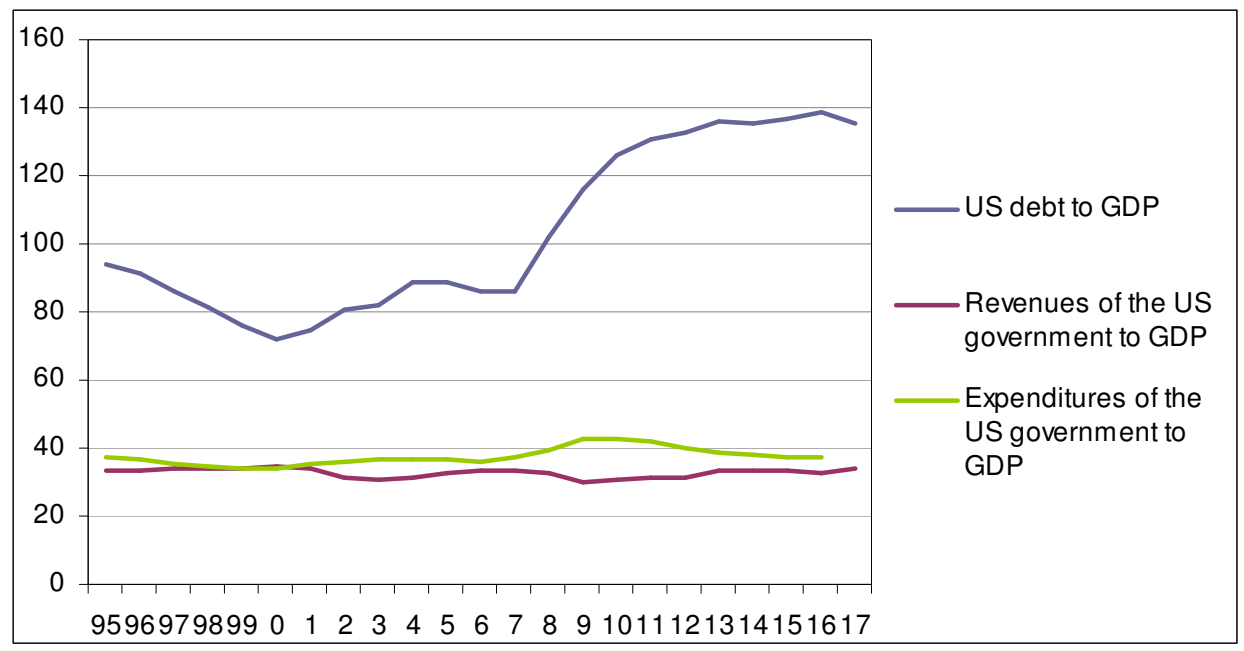

a) the USA



b) Germany 
Anti-cyclical fiscal regulation of the worldwide countries' economies - opportunities for Tkraine



c) Sweden

${ }^{*}$ Created by author, based on $[1 ; 2 ; 3 ; 4 ; 5 ; 6]$

Analyzing Fig. 2 (a; b; c), it can be concluded that the countries under consideration differ in the specifics of the fiscal policy implementation. Some countries have a social-oriented model of fiscal policy, while others use the principles of a liberal model. The main figure of merit is in the different combination of discretionary and non-discretionary fiscal instruments.

Analyzing the macroeconomic indicators of the USA, Germany and Sweden, we can say that these countries are different in relation to the state's participation in the GDP redistribution through the budget. Particularly, the fiscal policy of Sweden is clearly socially oriented - the country has a high level of GDP redistribution through the country's budget. The indicator of budget revenues was not lower than $50 \%$ during the analyzed period, the highest indicator of GDP redistribution was recorded in 1999, its value was $57 \%$. At the same time, the Swedish budget is balanced, there was an insignificant deficit for some years, and in the period of 1999-2008, the state recorded a budget surplus, which helps to suggest about the formation of a stable fiscal space. Taking into account the macroeconomic parameters of the country, Sweden is independent of the need to attract the additional financial resources from external and internal lenders. Since 1999, Sweden has been able to significantly reduce the level of public debt. In 1998 the level of debt was 82.8\% of GDP, then in 1999 it was 
ISSN 2519-4070

$73.1 \%$ of GDP, and in the following years it decreased and fluctuated within $64.8 \%$ in 2003 and $51.4 \%$ in 2008 . The analyzed indicators show the reasonable fiscal policy with obvious signs of acyclicity and social orientation.

The financial space in Sweden made it possible not to experience significant negative consequences in the country's socio-economic life during the financial and economic crisis of 2008-2009. In the crisis year of 2009, Sweden's debt was $55.2 \%$, budget expenditures - 52.69\%, income - $51.99 \%$. Fiscal imbalances were insignificant during the crisis: the debt level slightly increased by $3.8 \%$ compared to 2008 , the budget was executed with a slight deficit of $0.7 \%$. However, such imbalances are minor and absolutely harmless to the economy of the country. The fiscal policy that is carried out in Sweden is countercyclical. Particularly, in conditions of economic growth, the level of budget expenditures and the indicator of redistribution of budget revenues with a clear reduction of the public debt level increased. While in the context of the economic downturn, there is a slight increase in the budget deficit, which is compensated by a slight increase in public debt in relation to GDP. However, in the period of budget surplus, the government is able to form a significant supply of stability, which confirms the lack of a need to raise the level of public debt to critical parameters. Sweden's public debt is in the range of inconsiderable acceptable parameters - it does not exceed $60 \%$.

If we talk about the fiscal parameters of Germany, it is important to note that this country uses a social-oriented model of fiscal policy, with a high level of redistribution of gross domestic product through the country's budget. Germany's budget revenues range from $42.6 \%$ of GDP in 2004 to $46 \%$ in 1999. While budget expenditures are in the range of $43.9 \%$ in 2016 and $54.7 \%$ in 1995 . The highest budget deficit was recorded in 1995 at the level of $9.5 \%$ of GDP, which was the highest indicator for the entire period chosen for the study. However, since 1996, we can see a reduction in the budget deficit and its regulation according to the parameters set by fiscal rules, that is up to the limit of $3 \%$ of GDP. In 2000 , the budget surplus was $0.8 \%$ of GDP. Unlike Sweden, the budget of Germany, however, was scarce, but such a deficit was insignificant and was within the $3 \%$ of GDP. Therefore, we can state that the need for attracting credits in Germany is bigger than in Sweden.

The level of German public debt is higher than in Sweden. Since 1995, the level of debt has been permanently increasing, if in 1995 this indicator was $54,1 \%$ then in 2009 it grew to the level of $75,5 \%$. While the 2009 and 2010 crisis, the German government's debt began to increase, and in 2012 it grew to $88.1 \%$. It is important to note that during the 2009-2011 crisis in Germany, the government was using anti-cyclical fiscal policies. This is can be confirmed by the growth of expenditures from $43.6 \%$ in 2008 to $47.6 \%$ in 2009 , but the share of GDP redistribution due to revenues grew at a lesser pace - in 2008 the figure was $43.4 \%$, while in 2009 it grew to the level of $44.3 \%$. Considering the exigency to finance additional expenditures, during the crisis, there was a need for 

countries' economies - opportunities for Tkraine

additional attraction of credit resources by the state. In 2009, the public debt grew to $75.5 \%$ compared to $68.1 \%$ in 2008 , and continued to grow in 2010 to $84.5 \%$, in 2011 it slightly decreased to $84.2 \%$, and already in 2012 increased again to $88.1 \%$, which is the largest indicator of Germany's public debt for the entire analyzed period.

Therefore, the high level of state interference in the economic processes is more noticeable during the crisis, when the government applies instruments of anti-cyclical fiscal policy. In the period of economic global depression, the government of Germany raised the level of governmental expenditures, the level of deficit of the public debt increased, which is considered to be a classic mechanism for using anti-cyclical fiscal instruments. Throughout the reviewed period, the fiscal policy of this country can be called anti-cyclical. Particularly, every year, during the rise, the government of the country resorted to an increase in the level of GDP redistribution through the budget revenues (while the level of deficits was low). During the rise, the state did not resort to the accumulation of public debt, which is also clearly visible.

Another model of the fiscal relationship is in the United States of America, where the fiscal policy was liberal throughout all the reviewed period. The level of redistribution of public finances through GDP was always lower than in developed European countries. Also in the country, (throughout the analyzed period) there was an accumulation of public debt, which is much higher than in European countries. However, during the economic crisis, the United States government was using instruments of anti-cyclical, discretionary fiscal policy.

The level of US budget spendings from 1995 to 2007 ranged from $34 \%$ to $37 \%$, then, during the crisis of $2008-2011$, this figure increased to $42.89 \%$ in 2009. While budget revenues reduced to $30.14 \%$ in 2009 compared to $32.45 \%$ in 2008. It is important to note that during the crisis, the USA had a significant deficit of the federal budget. In 2009, the deficit was at the level of $12.7 \%$. The budget deficit of the United States is much higher compared to the European Union countries. The US government increased the country's public debt in order to cope with the budget deficit. In 2007, the government debt was $86.3 \%$ in relation to GDP, while in 2008, it increased and in 2009 it grew up to $115.8 \%$ in relation to GDP, in $2010-125.8 \%$, and in 2016, the share of public debt came up to $138.5 \%$ in relation to the United States GDP. The accretive level of the US public debt can indicate the major negative effects of the financial and economic crisis and the need to attract significant level of financial resources in order to stabilize the country's economy. This confirms the prevalence of the Keynesian model of fiscal relations, which is more prefered in leading European countries than the classical one that is used in the United States during the period of economic equilibrium. This system is incapable of being effective during the crisis and therefore, it changes to the system of fiscal relations with a discretionary (with wide participation of the government). In the context of the economic crisis, the United States' Government needs to turn its self-regulation policy to 
discretionary policy. Also, an anti-cyclical fiscal policy is widely used, in the case of the great need to «calm the economy down» quickly.

The analysis of the economic situation during 1995-2017 draws us the next conclusions: in the three leading countries of the world, (with clearly expressed social-oriented mechanisms of fiscal policy in Sweden and Germany, and a clear orientation of the US government to self-regulatory processes), the government (paternalistic) regulation policy has a greater effectiveness than the liberal fiscal policy.

The dynamics of the gross domestic product in Poland and Slovakia, which are the countries of the post-socialist camp, (and states that extremely quickly managed to achieve high economic development) is extremely interesting from the position of Ukraine, which was in the same conditions and at the same egress point. It is also important to research the models of fiscal policy in these countries that have influenced the rapid economic development of Slovakia and Poland (Fig. 3).

Analyzing the data shown in the figure, it can be noted that Poland and Slovakia are similar in nature of the fiscal policy implemented.

If we analyze the macroeconomic indicators of Poland, the following conclusions can be drawn. The state has quite high indicators of redistribution of gross domestic product through the budgets. Since 1995, budget revenues have fluctuated within $40 \%$ of GDP. The highest figure recorded during the reviewed period is the 1996 figure of $46.6 \%$ of GDP that was reallocated through the revenues of Poland's budgets with the expenditure level of $51.14 \%$ of GDP. Every year, the fiscal economy of Poland was being reduced, and that can be evidenced by the figures for the redistribution of GDP due to the budget revenues. In the crisis of 2009-2011, the income figure fluctuated within $37.79 \%$ in 2009, and gradually increased in the following years of 2010 and 2011. However, the value of the indicator did not exceed the value of $39.05 \%$ in relation to GDP. Such the indicators are lower than in the period of economic equilibrium (economic growth). However, in times of crisis, the level of government spendings increased. If, in 2007, expenditures amounted to $43.2 \%$, then in 2008 they increased to $44.29 \%$ of GDP, in 2009 - up to $45.04 \%$. Also, during the financial and economic crisis in Poland, the level of public debt increased in 2008 , the state debt amounted to $53.4 \%$ of GDP, and in 2009 it grew up to $56.7 \%$. Such growth continued during the following analyzed periods. The highest value of the state debt was in $2016-72.5 \%$ in relation to the gross domestic product. 
Fig. 3

The dynamics of government debt, revenues and expenditures of the government in Poland and Slovakia in 1995-2017 (\% of GDP)*

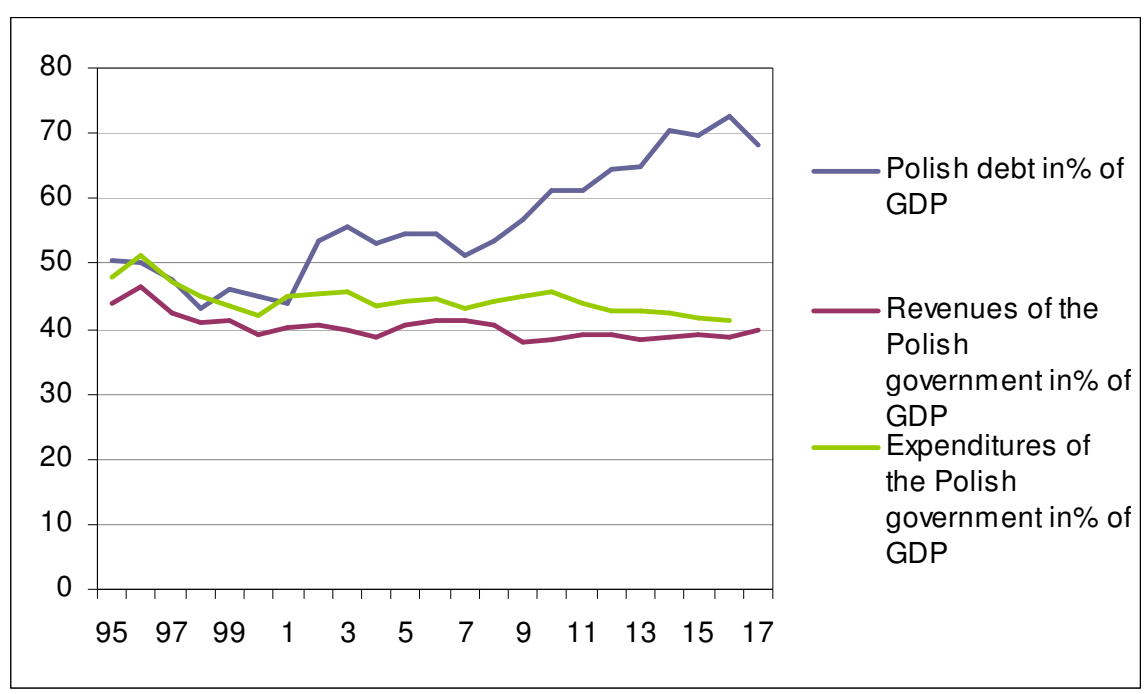

a.)

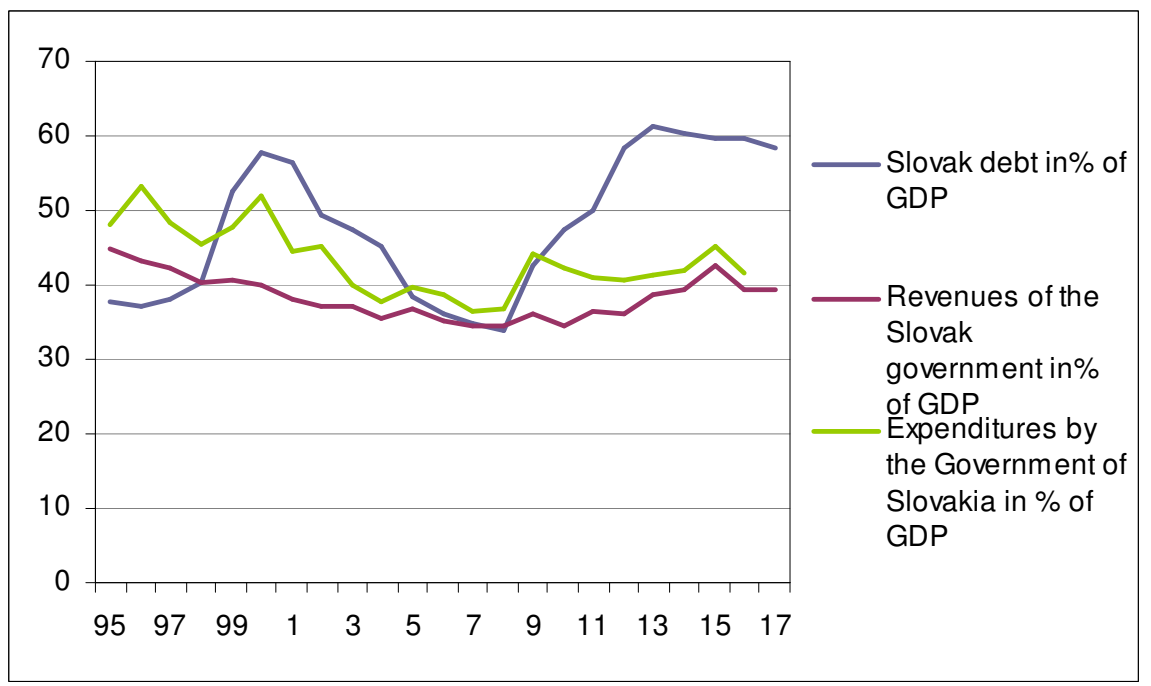

b.)

${ }^{*}$ Created by author, based on $[1 ; 2 ; 3 ; 4 ; 5 ; 6]$ 
Taking into account the analysis, we can state about the polish clearly expressed anti-cyclical fiscal policy during the observed period and, particularly, during the crisis years. This can be evidenced by the growth of the budget deficit against the background of increasing expenditures and moderate income growth, what can be explained by the devaluation of the national currency during the periods of crisis. Despite of that, there was a significant increase in public debt in the state as a necessary step to cope with the budget deficit and additional financing of budget expenditures. These signs of implemented fiscal policy specifically help to claim that Poland used the anti-cycled fiscal policy. The measures of reasonable fiscal anti-cyclical policy ensured GDP growth throughout the analyzed period, despite the global financial crisis. Among all the reviewed countries, the Polish government's fiscal policy can be estimated as one of the most effective, which helped to increase GDP more than 6 times during $1991-2017$.

The implemented fiscal policy of Slovakia is effective and similar to the implemented policy in Poland. It can be characterized as a socially-oriented fiscal policy, with a moderately high level of GDP redistribution through the country's budgets. By 2009, budget revenues in Slovakia ranged from $44.81 \%$ in 1995 to $34.51 \%$ in 2008. Budget expenditures during the period of economic formation in Slovakia were also quite high: in 1995 the level of expenditures amounted to $48.15 \%$ of GDP; the most unstable and deficit year for the whole analyzed period was in the 1996, when budget expenditures increased to $53.09 \%$ at income ratio at the level of $43.37 \%$ in relation to GDP.

The Slovak government succeeded in stabilizing the country's economy and ensuring a rapid increase in GDP. The main factor of economic development was an effective fiscal policy, which is meant to implement measures in order to balance the budget and to ensure the safe level of budget deficits. A certain negative impact on the economy of Slovakia happened due to the financial and economic crisis of 2008-2009. In these years, budget revenues amounted to $36.28 \%$ in 2009 , which is somehow higher than in 2008 . However, along with a slight increase of the revenues, a significant enlargement in budget expenditures was observed from $36.93 \%$ in 2008 to $44.08 \%$ in 2009 in relation to GDP. Though, the public debt increased from $33.8 \%$ in 2008 to $42.5 \%$ in 2009 , the value of government debt in Slovakia did not exceed $61.2 \%$ in 2013. What was the clear compliance of the Slovak government according to the fiscal rules introduced in the EU.

The analysis of Slovakia's macroeconomic indicators helps us to claim that the the state's fiscal policy has the anti-cyclical nature with the signs of social orientation and a moderately high level of GDP redistribution through the country's budget.

Consequently, the state fiscal policy of Poland and Slovakia is traditional for the countries of the European Union. It is based on the principles of the Keynesian economic theory, which defining characteristic is the high level of 

countries' economies - opportunities for Tkraine

state participation in the economic processes of the country, with a reasonable level of public debt. Fiscal policy has a major role in the economic development of these countries and helps to stabilize the economy in times of crisis and of economic downturns.

The economic processes of Iceland and Greece deserve for attention: Iceland as a country of the European continent, and Greece as a member of the European Union were characterized by high rates of economic development, a high level of welfare of citizens and social protection. The analysis of the GDP growth in the pre-crisis period was high, but during the financial and economic crisis, Iceland and Greece were affected by its negative impact the most. These countries have a big level of decreasing in all macroeconomic indicators (without any exception), and they can not be stabilized yet. (Fig. 4). The negative macroeconomic conditions can be explained by non-effective steps of the countries' governments in the sphere of ensuring long-term economic equilibrium.

The analysis of macroeconomic indicators in the dynamics, represented in Fig. 4 (a; b) helps us to draw next conclusions. During the reviewed period, the revenues of the Greek government grew each year. If in 1995 the indicator of GDP redistribution through the budget was $36.27 \%$, then in 2001 it increased to $42.36 \%$ in relation to GDP. In the next three years this figure slightly reduced to $38.79 \%$, but in 2008 , it started to grow again. In the crisis year 2009 , budget revenues declined to $38.94 \%$. There was also a high level of public expenditure, ranging from $43.71 \%$ in 1996 to $47.07 \%$ in 2007 in Greece. However, during the period of the economic crisis, the level of government expenditures was significantly increased to $54.07 \%$ in $2009,52.47 \%$ in 2010 , and $54.08 \%$ in 2011 . The highest expenditures were observed in $2013-62.17 \%$ in relation to GDP. The following years, this figure slightly decreased. The budget of Greece is characterized by a high level of deficit, its highest value was recorded in 2009 at the level of $15.13 \%$ of GDP (that was a significant violation of the fiscal rule of the budget deficit adjusted in the European Union.) The negative trend of Greece's public debt has been observed since 1995. This year's Public debt amounted to $97.8 \%$ of GDP, while in 2009 it grew up to $135 \%$ of GDP, and already in 2017 it amounted to $188.8 \%$ of GDP. High level of government debt is a threatening condition that indicates a fragile financial situation in Greece, a difficult economic situation that can have serious consequences and become a threat to the security of the state.

The analyzed situation is the evidence of the government's failure to pursue anti-cyclical fiscal policy in the time of crisis. That means the lack of financial sustainability and professionalism of these countries' managerial state institutions. In the conditions of the crisis, the government of the country carried out the measures that can be described as measures of cyclical fiscal policy. Particularly, during the crisis period, besides the growth of expenditures, the government tried to increase the tax burden. 


\section{Fig 4}

The public debt dynamics, government revenues and expenditures in Greece and Iceland in 1995-2017 (\% of GDP) ${ }^{\star}$

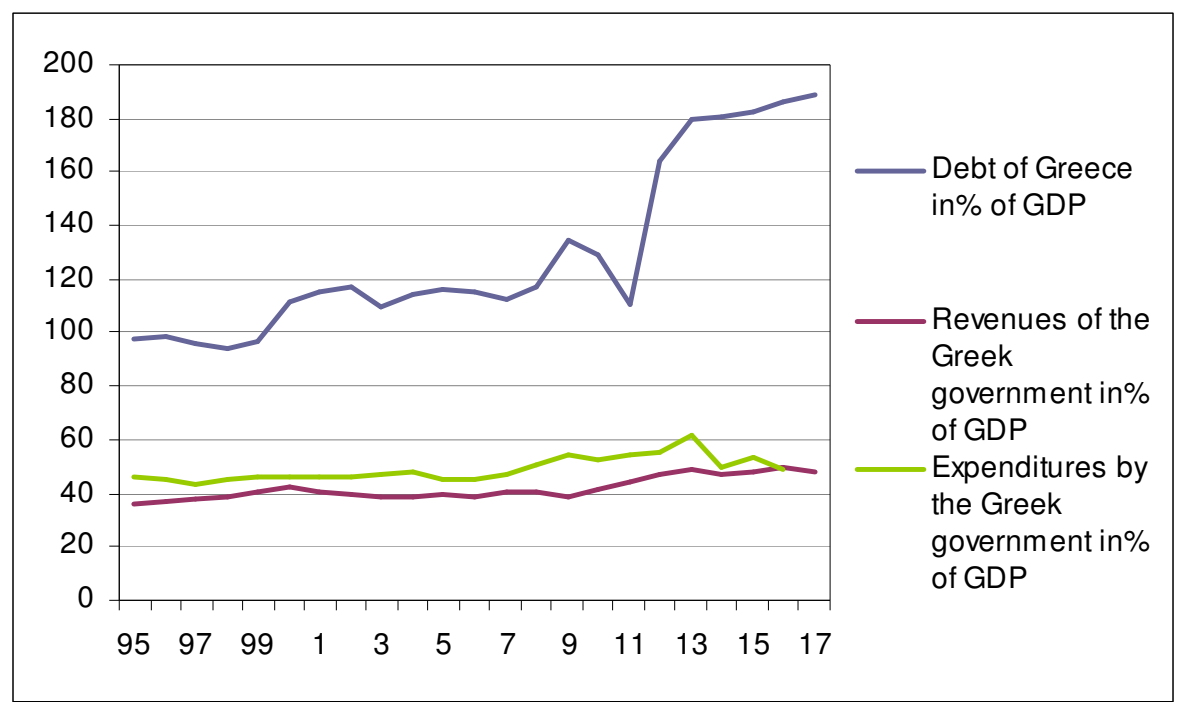

a.)

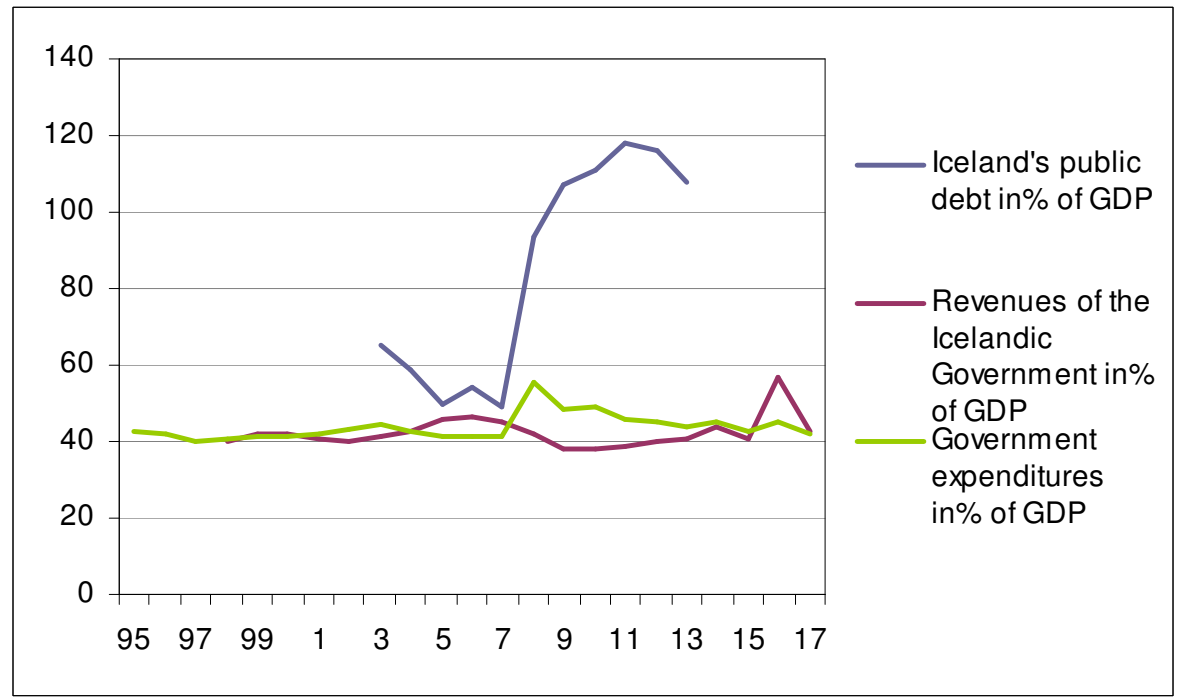

б.)

${ }^{*}$ Created by author, based on $[1 ; 2 ; 3 ; 4 ; 5 ; 6]$ 

countries' economies - opportunities for Tkraine

That did not allow to stabilize the economy in the medium and long term. Also, in order to finance the expenditures, the Greek government had to attract government borrowings, which reached the critical level in 2017. Scientists have proven that government spendings along with the government borrowings are effective only in the short term, while in the long term they create an additional financial burden on the budget. And as a result, it leads to the unpopular government measures: to raise the level of tax burden, to increase maintenance expenditures and the payment of the pre-formed debt instead of spending finances on social expenditures and expenditures for the economy development (capital expenditures).

Iceland was marked by a rising growth of macroeconomic indicators and annual GDP growth in terms of the world's economic equilibrium. In the period of crisis, the country suffered huge economic losses, which reflected in a significant increase in budget deficits, increasing spendings and in a significant increase in public debt. In the conditions of economic stability, there was a high level of social and economic development with the balanced budget indicators.

Analyzing the dynamics of fiscal macroeconomic indicators, we can state that in the times of economic equilibrium, government debt figures were within acceptable and admissible indicators. In 2003, the debt amounted to $65.4 \%$ of GDP, before 2007 it reduced and amounted to $49.5 \%$ of GDP. During the reviewed period, Iceland's budget was balanced: the deficit did not exceed $3 \%$ by 2008 , and it was surplus in 1999, 2000, 2005, 2006, 2007. However, during the economic crisis, macroeconomic indicators had diametrically changed and that caused negative consequences in the country's economy. In 2008, the country's budget deficit amounted to $13.65 \%$ of GDP, in $2009-10.29 \%$, in $2010-10.77 \%$. And in the following years, the government managed to stabilize Iceland's economy, the main factor of such stabilization was the growth of external borrowing. It is important to state that in the conditions of the crisis, the indicator of income reallocation through the country's budget reduced, though, at the same time the country's debt increased to a threatening level. If in 2005 the country's debt amounted to $49.5 \%$ of GDP, then in 2008 this indicator grew to $93.7 \%$, in $2009-106 \%$ of GDP, in the following years the indicator continued to increase and in 2012 it reached $115.9 \%$ of GDP, actually doubled in comparison with 2003. However, it can be stated that the Iceland's government took anti-cyclical fiscal measures throughout the reviewed period. That follows from the analyzed macroeconomic indicators. During the period of economic equilibrium, there was an insignificant level of public debt, a budget surplus, while in the period of economic recession and crisis, budget revenues sharply decreased, while expenditures grew simultaneously with the growth of the country's debt ( public debt became the main source of financing from the government expenditures). However, the accumulation of public debt can not be regarded as a positive signal for the long-term economic development, and it can only be used for the short-term periods, as an instrument for dealing with the crisis and stabilizing the economy in a limited time. In recent years, Iceland's public debt has grown to an 
alarming level, which can have negative economic consequences in the future and affect the state's economic security.

The analysis of the macroeconomic situation in Greece and Iceland helped us to draw the following conclusions. The reason for the negative consequences in the economy is the lack of financial stability, the lack of financial resources of the government, the inability to effectively manage the existing resources. High level of government spendings is unsupported by a qualitative redistribution of GDP through the government budget revenues (high budget deficits). This issue have led to the need for a significant government debt accumulation, which can lead to equalization of the macroeconomic situation in the countries only for the short-term periods. Huge government debt only leads to the aggravation of fiscal and macroeconomic tensions.

In the light of the study, it is important to state that the governments of Iceland and Greece pursued a different fiscal policy type. If the Icelandic government used anti-cyclical fiscal policy during the reviewed period, which provided a faster process of stabilizing the country's economy, the Greek government did not have a stable financial environment (due to the lack of an effective strategy for economic stabilization during the crisis) and it was forced to pursue an unpopular pro-cyclical fiscal policy that was held in an unstable financial macroeconomic environment. The procyclicality of the measures that were taken by the Greek government can be confirmed by statistical macroeconomic fiscal data.

The analysis of macroeconomic indicators of the European countries and the United States can help us to describe the next conclusions. Each country is unique in accordance with their applied fiscal measures and it is distinguished by its peculiarity and certain features. However, we can clearly observe the usage of common parameters and measures taken (by governments) for macroeconomic stabilization in the countries of the European Union. Despite the peculiarities of macroeconomic development, countries like Germany, Sweden, Poland and Slovakia use similar mechanisms, mostly using the similar parameters. The level of government debt in countries is insignificant, budgets are balanced, which helps us to state their ability to quickly and effectively ensure the process of economic stabilization in a crisis and to pursue a socio-economic growth and development policy. The exception is the economic situation in Greece, which did not provide the proposed vector of economic development of other European countries and that eventually led to the negative consequences in the economy of this country. The lack of a stable financial environment forced the Greek government to use instruments of pro-cyclical fiscal policy.

If we talk about the financial policy of the United States of America, it is important to note next things: the government of the country uses the principles of liberal fiscal policy with a small level of GDP redistribution through the government budget and with a high public debt. That strategy was not successful in times of crisis, which led to the exigency of using tougher fiscal instruments of 
an anti-cyclical fiscal nature ( that can be clearly observed during a thorough analysis of macroeconomic indicators).

Iceland policy is similar to Sweden financial policy on the basis of Iceland's' geographical location. However, the limited economic potential, the high standards of living of citizens in Iceland, high rates of GDP redistribution through the country's budget, ultimately led to the significant losses in the economy and to a deep crisis with a high level of accumulated public debt. Nevertheless, a certain margin of financial stability allowed Iceland to implement anti-cyclical fiscal policies, which enabled (in the last analyzed periods) to stabilize the economic situation in the country.

The situation of economic development and dynamics of the main state fiscal macro indicators in Ukraine is asymmetric (Fig. 5).

\section{Fig. 5}

The public debt dynamics, government revenues and expenditures in Ukraine in 1995-2017 (\% of GDP) *



${ }^{\star}$ Created by author, based on $[1 ; 2 ; 3 ; 4 ; 5 ; 6]$ 
ISSN 2519-4070

The analysis of macro-fiscal indicators of Ukraine, helps us to draw the following conclusions. Based on the economic trends of Ukraine during 19952007, we can state that Ukrainian economy was sufficiently feeblish. The Ukrainian economy and its development can be classified by 3 periods.

First period - In 1991-2004, Ukraine's government debt ranged from $28 \%$ to $60.97 \%$ of GDP, while Ukraine's GDP in 1991-2004 did not exceed the indicator « $1 »$ to the base year of 1991 . This stage in the Ukrainian economy was called the stage of «lost opportunities».

During the second period of Ukrainian economy, (which in our opinion lasted from 2005 to 2013) the macroeconomic situation in Ukraine was endowed with such features. The budget of Ukraine was marked by the stability of fiscal indicators. After the «Orange Revolution» in 2004, until 2013. Budget revenues fluctuated within $25.6 \%$ in 2004, in 2005 this figure slightly increased to $29.7 \%$, in 2012 it was $30.8 \%$, in 2013 the indicator reduced to $29.3 \%$. During the analyzed period, the budget expenditures were higher than the revenues and fluctuated from 29.3\% in 2004, in 2005 expenditures increased to $32.1 \%$ of GDP, in 2012 the figure increased to $35.1 \%$, the budget deficit in 2012 was $4.3 \%$ of GDP, which is the third highest indicator in terms of the analyzed period. And in 2013, the budget deficit increased to $5.2 \%$.

If we observe the economic situation in Ukraine during the crisis of 20082009 , we can notice its significant influence on the economy of the country. The indicator of GDP redistribution through the budget revenues in 2009 was similar to the indicator of 2008 and amounted to $30.7 \%$, while in 2010 it reduced to $28.2 \%$. There is also an increase in the budget deficit in Ukraine. If the deficit in 2009 was $2.9 \%$, then in $2010-6.7 \%$. The increase in the budget imbalance was caused by the need to finance additional expenditures that appeared as a result of the economic crisis. In 2009 , expenditures increased to $33.6 \%$ in relation to GDP, in $2010-34.9 \%$ of GDP, which led to a rise in the deficit.

In order to offset the additional expenditures, the government tried to attract the additional credit resources. If in 2008 the level of public debt was $19.7 \%$ in relation to GDP, then in 2009 it grew to an indicator of $34.1 \%$, and in 2010 to $40.6 \%$, which meant a nearly double increase in debt, and indicated that the economic situation in Ukraine had been stabilized due to the state borrowings. However, under the conditions of the crisis, we can clearly observe the usage of anti-cyclical fiscal measures, which are manifested in the growth of government debt and state expenditures, and at the same time in the reducing the level of redistribution of gross domestic product through the budget revenues.

However, comparing with the other analyzed countries, Ukraine has special peculiarities of the political situation, and also there is a military aggression of the Russian Federation on the territory of Ukraine. That is why the periods of formation of the Ukrainian economy are divided according to the specific criteria: into the accordance with the events that took place in the state. The most interesting is the third period, which can be considered as the most difficult, considering the events that took place in Ukraine. 

countries' economies - opportunities for Tkraine

During the 2014-2017, the level of the redistribution of gross domestic product increased due to the revenues of the Ukrainian budget, which indicated the tax burden increase. If in the pre-war period in Ukraine (2013) the income ratio was $29.3 \%$ of GDP, and in compliance with the significant loss of the economic potential as a result of the occupation of Ukraine's part of the territory in 2014, the income rate reduced to $28 \%$ of GDP, then in 2015 and 2016, the growth of the economy's fiscal growth was $32.8 \%$, in 2017 the revenues of the budgets of Ukraine increased to $34,1 \%$. Despite the narrowing of the tax base in the pre-war period of 2012, there was an increase in the level of budget expenditures, which led to an increase in the deficit at the level of $4.3 \%$ in relation to GDP. The negative trends remained in 2013 and 2014, with expenditures at $34.5 \%$ and $33 \%$ relevantly, with a deficit of $5.2 \%$ of GDP in 2013 and $5 \%$ in 2014. In the following years, the Ukrainian government managed to stabilize the macroeconomic situation, which can be observed in the balanced Budget of Ukraine. In particular, the budget deficit in 2015 was $1.4 \%$, in 2016 $2.2 \%$, in $2017-1.3 \%$.

However, despite the stabilization of public finances, the state increased its public debt in order to repay the additional expenditures. They increased from $40.5 \%$ in 2013 to $81.2 \%$ in 2016 , but already in 2017 , the government debt reduced to $75.6 \%$.

Therefore, the analysis of the third period of economic development in Ukraine is characterized by both positive and negative aspects. Positive sides are the balance of the budget, compliance with the budget deficit in the range of $1.3-2.2 \%$, which reduced the need for additional attraction of credit resources. Negative consequences can be observed in the next things: the increase in the level of GDP redistribution through the budget revenues, which in the conditions of the crisis and the economic downturn is an ineffective measure that may reduce the ability of entities to invest themselves, and may also lead to the reduction in the spending power and to the lower demand. That causes a negative economic conjuncture and creates a threat to the growth of the shadow economy in terms of wage billing. As a result, the government of Ukraine was forced to attract additional credit resources. In the period from 2014 to 2017, the fiscal policy in Ukraine had specific signs of a «dual fiscal policy», which meant the simultaneous growth of all fiscal indicators in the terms of an economic downturn. However, as we can observe by the analysis of indicators in the other countries, only an effective anti-cyclical fiscal policy that is conducted by the government throughout the economic cycle can have a positive economic effect in the short, medium and long term.

The analysis of macroeconomic fiscal indicators in the leading countries of the world, in the fast-growing countries that were affected the most by the financial and economic crisis, and Ukraine, make it possible to distinguish the peculiarities and the specifics of the fiscal policies of each of the countries, it also makes it possible to determine which instruments are effective and can be used in the Ukrainian practice (Fig. 6). 
Fig. 6

Fiscal policy in countries around the world by the types and models at different stages of the economic cycle

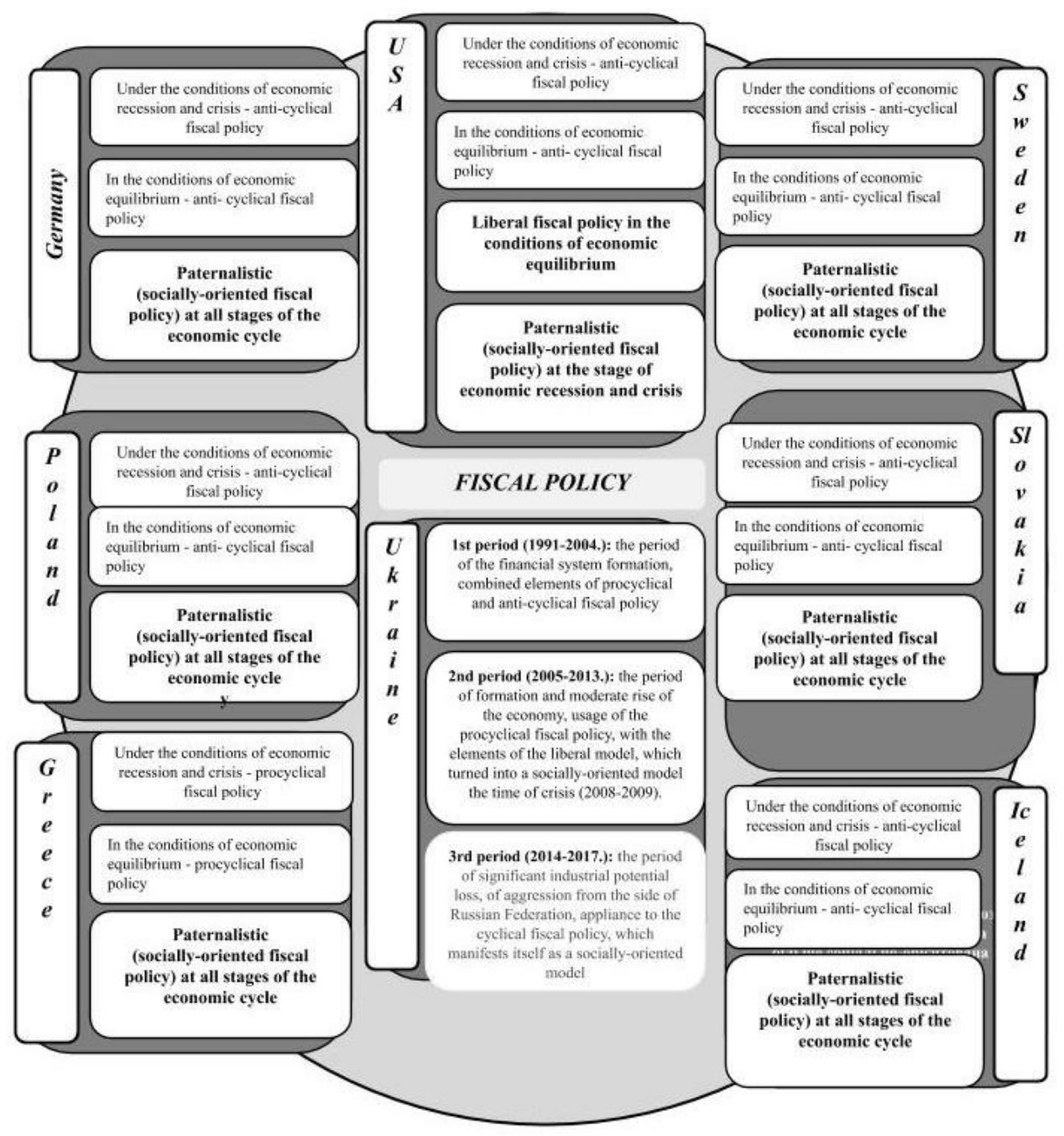

${ }^{*}$ Created by the author, based on $[7 ; 8 ; 9 ; 10]$ 

countries' economies - opportunities for Tkraine

After analyzing the economies of the world, we can draw the following conclusions. More uncrushable in the terms of the economic imbalances and crises are the economies of social-oriented, even harsh paternalistic type, which can be confirmed by the analyzed economic indicators. The paternalistic fiscal model, with the great power of the state to regulate the economic processes, allowed European countries to prevent the devastating effects of the financial and economic crisis. In contrast to the severe consequences of the crisis, that were faced in the countries with a liberal fiscal model, even in spite of their power and strength. Particularly, the US government used a liberal model in the precrisis period (during the period of economic equilibrium), which provided a boost in the economic indicators, though, in times of the crisis, the state's participation in economic processes became more significant. And the state's policy became a sign of the Keynesian model of the tough fiscal regulation by the state.

\section{Conclusion}

Therefore, it is appropriate for Ukraine to impose those countries' experience that use a socially oriented model of fiscal policy to regulate the economic processes. This model of fiscal policy, as confirmed by the analysis, is more effective both in conditions of economic equilibrium and in times of crisis. However, as it was mentioned above, the problem of economic development of Ukraine's economy is not about the legislative models of instruments and mechanisms of fiscal policy (which according to macroeconomic analysis has a sufficiently satisfactory parameters). And yet, the greatest problem of a rapid economic growth in Ukraine is the problem of public administration, institutional imbalances, corruption, erratical distribution of material wealth between the richest and poorest citizens, an unstable investment environment, incompletely effective system of the state and local governments.

\section{References}

1. GDP (current US\$) [Online] // worldbank. - 2018. - Available from: https://data.worldbank.org/indicator/NY.GDP.MKTP.CD.

2. General government revenue [Online] // OECD. - 2018. - Available from: https://data.oecd.org/gga/general-government-revenue.htm.

3. World Data Atlas [Online] // Knoema. - 2018. - Available from: https://knoema.ru/atlas. 
4. General government spending [Online] // OECD. - 2018. - Available from: https://data.oecd.org/gga/general-government-spending.htm\#indicator-chart

5. General government gross debt - annual data [Online] // Eurostat. - 2018. Available from: https://ec.europa.eu/eurostat/tgm/refreshTableAction.do? tab=table \&plugin $=1 \&$ pcode $=$ teina225\&language $=e n$.

6. Government expenditures, percent of GDP - Country classification [Online] // theGlobalEconomy.com. - 2018 . $\quad$ - Available from: https://ru.theglobaleconomy.com/rankings/Government_size/.

7. Krush P.V. Money and credit [Online] / P.V. Krush, O. V. Klymenko Available from : https://pidruchniki.com/17810409/finansi/groshi_ta_kredit.

8. Kravchuk U. O. Макроекономіка [Online] / U. O. Kravchuk - Available from: https://poznayka.org/s47011t1.html.

9. Yefimova O.G. Economics for lawyers [Online] / O. G. Yefimova // Flint Publishing House. - 1999. - Available from: http://bibliograph.com.ua/ economika-dlya-yuristov/index.htm.

10. Bogdan I.V. Procyclic or anti-cyclical fiscal policy: diagnostic methods / I. V. Bogdan. // Academic journal «Ukraine economy». - 2013. - №3. C. $45-57$. 